\title{
THE EFFECT OF COVID-19 ON THE REAL ESTATE INDUSTRY IN INDIA
}

\author{
Rashmi Jaymin SANCHANIYA* \\ Gujarat Technological University, Ahmedabad, India \\ "Corresponding author's e-mail: Rashmi.Sanchaniya02@gmail.com
}

\begin{abstract}
The world economy seems to be experiencing one of the most severe downturns in recent memory. The latest pandemic has had a detrimental effect on the economies of several nations, including India. The International Monetary Fund forecast India's growth rate at $1.9 \%$ for fiscal year 2021, down from $5.8 \%$ previously. This poses a significant challenge to the Indian economy. The resumption of work was complicated by the workers' surprising return to the employers from underground. Developers struggled to locate enough jobcreating jobs due to the labour market severe constraints. The populace is burdened by the great pestilence that threatens the nation. Indian real estate, which was still emerging from the implications of demonetization (November 2016) and other changes, was jolted by this pandemic, with building development halted and real estate transactions paused. Indian real estate should plan itself for a post-COVID-19 environment and be prepared to take several new and technology-driven moves to get back on track. The secondary data research methodology is used in this paper and the aim of the research is to discuss the pre-pandemic real estate market and the effect of COVID-19 on the Indian real estate market. Additionally, it discusses the risks and prospects confronting various real estate industry participants.
\end{abstract}

Keywords: COVID-19, global economy, Indian real estate.

\section{INTRODUCTION}

The World Health Organization (WHO) stated that it was on track to declare a global public health emergency and pandemic on about 11 March 2019, and businesses worldwide were bracing for a severe effect. Due to the spread of the plague, trade, imports, and foreign exchange rates have been profoundly disturbed in the world. According to early reports, the COVID-19 outbreak is expected to claim many lives. National GDP (Gross Domestic Product) is nearing its troughs, and the world continues to be during the most devastating global recessions in history. Due to the depressed labour market, developers were constrained, and consumers' ability to buy a property decreased as well, developers no longer had the potential to seek out contractors to expand their company. Along with suppressing the $\mathrm{H} 1 \mathrm{~N} 1$, the pandemic had a major impact on house prices and fresh land releases. In the six months after this issue became public, demand for real estate increased. Individuals are using some of their bargaining power, and the market favourable reaction indicates that they expect the gain will offset the expense (Adams-Prassl et al., 2020). 


\section{COVID-19 IMPACT ON REAL ESTATE IN INDIA}

According to Cushman \& Wakefield (2021), India's commercial real estate market is reasonably priced in comparison with the city's overall financial health and offers enough opportunities. The pandemic impact on global commercial markets is also evident in farm animal production, as the latest phenomenon has recently spread to animal farms. If only the short-term repercussions are considered, leasing and cooperating with companies would be severely harmed. The commercial real estate industry will eventually recover from the crisis, although it will be gradual. According to estimates from the company's primary sector, provider of commercial room in India, the prevalence of this disease has delayed ventures, the industry is glutted, implying that projects are in short supply, affecting demand and, therefore, costs and rental rates.

The COVID 19 pandemic, which brought the globe to a halt in 2020, unsettled various sectors of the global economy. Businesses have been severely affected, prices have fallen to new highs, and COVID-19 has shaken the real estate market, which has been on a growth curve in recent years. Since 21 March 2020, nearly 1.3 billion people have been quarantined, effectively shutting down the nation's largest business. According to the ANANROCK H1 2020 PAN India Residential Market report, the quarter with the greatest effect was Q2 2020, with the fewest launches since 2013. This year, fresh launch supply decreased by $97 \%$ relative to the same quarter last year and by $98 \%$ compared to Q1 2020. Both residential and industrial real estate was impacted in terms of sale and purchase. Due to a lack of materials and labour, the whole process has been slow and unpredictable. Even though developers and builders have braced for delays, the revival in the real estate market has been pushed out further. The real estate market rebound is mostly contingent on the labour force. The employment situation does not seem to be encouraging.

The term "real estate purchase" refers to the acquisition, sale, and development of properties (both residential and non-residential buildings). There are some advantages of real estate investing. For one, it offers higher and more stable dividends, a high tangible value, and an investor may obtain a periodic gain in the form of rent revenue, as well as tax benefits. The real estate sector provides a sizable contribution to India's GDP, accounting for approximately $6 \%$. By 2030, real estate in India is expected to reach a market value of US\$ 1 trillion, up from US\$ 120 billion in 2017 and contributing $13 \%$ to the country's GDP by 2025 .

Hungary tops the record with a $15.4 \%$ valuation growth rate, followed by Luxembourg at $11.4 \%$ and Croatia at $10.4 \%$, respectively. Slovakia was ranked fourth with a home evaluation score of $9.7 \%$, Latvia was ranked fifth (9\%), the Czech Republic was ranked sixth (8.7\%), China was ranked seventh (8.5\%), Jersey was ranked eighth (8.5\%), Mexico was ranked ninth $(8.4 \%)$, and Russia was ranked tenth $(8.1 \%)$. Costs increased at a $3.7 \%$ annual rate across 56 countries. It is worth noting that this is the slowest rate of growth over six years. In September $2019,91 \%$ of all nations and regions assessed enrolled in stagnant or optimistic development. The COVID-19 pandemic that began in China has affected citizens worldwide. It has brought the market cycle and economic activity to a stop, and the effects can be found in a wide variety of sectors. The Indian real estate market, 
which was already suffering owing to policy reforms and the liquidity crisis, is now confronted with another obstacle: the effect of the coronavirus on the Indian economy and its implications for the real estate industry. Indian land division is the second largest employer after agriculture, and the pandemic impact would have an impact on those working in this industry (Del Giudice et al., 2020; D'Lima et al., 2020).

\section{LITERATURE REVIEW}

According to Anarock (2020) study, in the Indian real estate in normal times, the advancing time frame usually observes an increase in real estate activities because of folk festival festivities, as new deals sprout up. The upcoming excursion period for Indian colleges, which runs from April to June, also provides time for homebuyers to make purchase decisions. Regrettably, 2020 is shaping up to be unprecedented. The nationwide lockdown, which lasted until mid-April, brought an end to all drills. As it is evident, venture destinations have been closed, site visits have ceased, and construction activity has come to a grinding halt, adversely impacting deals in the long run. Additionally, developers have delayed the launch of their latest ventures for an unknown time. Apart from the industrial sector, the business sector is still vulnerable to the COVID-19 aftermath.

JLL (2020) indicates COVID-19 global real estate ramifications. Now, speculation activity can slow as valuation difficulties and increased vulnerability impair investors' ability to appropriately price danger. Despite adequate liquidity through stock and debt markets, loan specialists and speculators continue to operate in a valuation disclosure phase. Despite shifts in sentiment and behaviour, the general trend has been toward greater allocation to real estate, and the author of the study sees little reason for this trend to reverse in the medium to long term, considering the benefits of such investments. According to FICCI (2020), the year 2019 was a trying one for the real estate market, which continues to struggle with financing shortages amidst problems plaguing the NBFC and banking sectors. The situation has been compounded by the monetary impasse, which has resulted in low demand.

Additionally, fundamental shifts have occurred in the industry because of recent events such as demonetization and the introduction of the RERA and GST. The company intended to recoup its losses from the lengthy shutdown in 2020. However, the COVID-19 pandemic could put a brake on India's land market, provided the anticipated decline in demand. Until now, the coronavirus outbreak has had no impact on real estate. In either event, a prolonged coronavirus infection may have a detrimental impact on real estate market prospects.

This research addressed growth and administrative issues by quantifying the consequences and risks associated with implementing the COVID-19 epidemic (Tanrıvermis, 2020). Pandemic-related costs and losses have been described as an unpredictable phenomenon that reduces land market growth, property rates, property values, and revenue projections for the whole industry. It is one of the first research to examine the effect on low-risk real estate firms. Another contribution is the invention of a Covid-19 Risk Factor to assess a company's susceptibility to 
Covid-19 risks. The risk factor is unrelated to other stock market factors and arises because of the repeated volatility in global Covid-19 events recorded (Milcheva, 2020).

Introduced the contagion impact of the COVID-19 outbreak: Another recipe for India's economy to crash. This article contextualizes COVID-19 by using a few simple numbers and economic terms to demonstrate how much development is occurring in India. Rather than relying only on standardized numbers, they are used in macroeconomic analyses, travel and tourism, transportation, industry, labour power, the environment, and human resources, as well as trade research. The findings indicate that if the government is unable to implement an appropriate strategy, India will already face a health crisis and a very tough economy in the future (Singh \& Neog, 2020). According to an article (Gujral et al., 2020), commercial real estate could be able to do more than respond to coronavirus. In the post-coronavirus world, most buyers and operators are reconsidering all capital decisions. Due to the severe uncertainty around periods of cash-flow deflation and exit capitalization rates, it is exceedingly challenging to underwrite acquisitions and incremental capital investment with confidence. And some in the private sector who are not now in financial difficulty plan to keep assets through the crisis. Others see the current condition as a valuation challenge rather than a value concern. However, investor sentiment is swayed by record-high amounts of dry powder.

Few similar studies (Chauhan \& Kapoor, 2021; Tanrıvermis, 2020; Uchehara, 2020) share their perspectives on the coronavirus effect on the Indian real estate industry. Novel Coronavirus has had a disproportionate impact on the Indian real estate. In the first three months after the epidemic, it suspended construction and significantly reduced interest from prospective buyers. Global crises and their effects on project operation, expenses, and market growth have dubbed an "unpredictable" case. Travel bans and prohibitions have stifled tourism, while real estate transactions, including store, workplace, and especially hotel, have suffered. Strategic, operational, social, networking, and operational processes, as well as living standard improvements provide a continuous review of our strategy, programmers, programs, and contact schedules. Turkey's government merely wishes to revitalize the real estate market by the sale of modern and industrial property, but their long-term reforms are insufficient. One aspect that had not been investigated was the duration of the effect and the financial pressure it would impose in March 2020, when the first case was recorded. The index results and data from the previous recession were used to predict a significant impact on the economy. As a result, two procedures are used: first, the potential patterns in the $\mathrm{V}$, $\mathrm{U}, \mathrm{W}$, and L supply chains are mapped. Additionally, using a pandemic risk prevention strategy will aid in product safety. The results indicate an emerging movement toward contract clause modification, which could be interpreted as an industry reaction. This research is valuable because it enables a long-term solution to any potential pandemic in the developed world.

Similarly, based on reliable data, indicators are used to assist in analysing the current state and forecasting the potential growth of villages and communities along the Baltic Sea shore. A GIS is one of the most effective tools for presenting and analysing statistical and geospatial data utilising spatial analysis techniques such as 
geoprocessing (Tupenaite et al., 2017). Other technological advancement can also give huge impact on real estate industry over the globe, for example, negatively charged particles of amber can be used in mask, which helps repel Covid viruses, which also have negative charge (L,ašenko et al., 2016 and Gaidukovs et al., 2016). In India, where the people cannot be vaccinated in a short period of time due to huge population, this may be a viable option for real estate and other industries in the present environment.

\section{OBJECTIVE AND METHODOLOGY}

The objectives of this research paper are to conduct research on the Indian real estate market prior to the implementation of COVID-19, to comprehend the consequences of COVID-19 and to gain an understanding of the threats and opportunities facing mortgage holders, builders, and the real estate workforce, and to draw conclusions.

This research article is focused on secondary sources of information. The data for this article come from numerous real estate surveys, including those from FICCI, Knight Frank, the World Economic Forum, and Anarock. This essay draws from a variety of articles written in the Economic Times and other secondary references.

\section{RESULTS}

India is one of the world's top ten economies. After overcoming numerous obstacles such as demonetization, reforms, and GST, it was thought that Indian real estate will rise and become stronger than ever. Let us examine the predictions made prior to the outbreak of this pandemic. The industry's market value was USD 120 billion in 2017 and was expected to rise to USD 180 billion by 2020 . Additionally, it would reach USD 650 billion in 2025 and USD 1000 billion by 2030 . This sector contributed $6 \%$ to India's GDP in 2015 and was expected to contribute $13 \%$ in 2025. The sector employed 40 million workers in 2013, 52 million in 2017, and was expected to hire up to 67 million in 2022, a $28.84 \%$ growth from 2017 to 2022 . However, much of this seems to be impossible to do now. Following the lockdown, the building industry will experience a labour shortage, since most employees have returned to their villages and transport restrictions will continue in any form.

FDI inflows have also slowed significantly; for example, the absolute FDI inflows between April and December 2019 decreased by $7 \%$. It is projected to continue to fall in the coming year. Commercial real estate, which has been seeing rapid development in recent years, will also be affected by the pandemic. Reduced GDP development and a world economy only suffering from COVID-19's wounds would have a detrimental effect on office production. In 2020 and subsequent years, supply and net absorption would be much smaller. The impetus for this forecast stem from the wake of the 2008 financial crisis. Additionally, the time span surrounding the holiday season, as well as the summer vacation period, which is suitable for fresh dispatches, has been dry for the sector. 
Given that real estate transactions are highly dependent on physical site visits, connections, conversations, and physical documents, the deals in 2020 could take a significant hit because of India's current COVID-19 episode. Numerous home buyers will propose deferring their selections to postpone site visits or to achieve any cost savings. Affordable housing is claimed to be targeted at the most influenced segments of the working population. These home buyers with limited income and a lack of telecommute offices may face financial hardship or even loss of employment, prompting them to reconsider their purchase decisions. With fair or subsidized housing units accounting for approximately $36 \%$ of the buy and wide unsold stock across the major seven urban areas as of Q1 2020, this segment was already experiencing difficulties. Additionally, the current pandemic episode has deteriorated the condition.

However, not everyone is bleak; each incident presents certain difficulties but often presents opportunities. The following table attempts to summarise the dangers and opportunities that consumers, holders, and builders face.

Table 1. Threats and Opportunity to Varying Degrees for Real Estate

\begin{tabular}{|c|l|l|l|}
\hline Participant & \multicolumn{1}{|c|}{ Investor (customer) } & \multicolumn{1}{c|}{ Constructor } & \multicolumn{1}{c|}{ Labour force } \\
\hline Risk & $\begin{array}{l}\text { Overdue delivery, pay } \\
\text { shortening, risk of } \\
\text { losing source of income } \\
\text { due to COVID-19 }\end{array}$ & $\begin{array}{l}\text { Projects may get delayed } \\
\text { or suspended, labour may } \\
\text { migrate to their } \\
\text { hometowns, buyers may } \\
\text { prefer completed projects } \\
\text { only, delayed delivery } \\
\text { deadlines }\end{array}$ & $\begin{array}{l}\text { Reduced pay, loss of job, } \\
\text { short of work }\end{array}$ \\
\hline Opportunity & $\begin{array}{l}\text { Lower interest rate and } \\
\text { home loans, personal } \\
\text { loans, deals on offer, } \\
\text { concession in property } \\
\text { tax }\end{array}$ & $\begin{array}{l}\text { No penalties due to } \\
\text { delayed delivery, } \\
\text { Delivery timings can } \\
\text { extend }\end{array}$ & $\begin{array}{l}\text { Adopt virtual tours and } \\
\text { implement new ideas like } \\
\text { e-broacher, social benefits } \\
\text { from government }\end{array}$ \\
\hline
\end{tabular}

The suspension of construction activities posed a greater danger to the engineers' financial power, which had not yet recovered from the Non-Bank Financial Companies (NBFC) crisis. Whatever the case, the pandemic can result in a short- to medium-term value revision. If the immediate to temporary effect is considered, commercial real estate would be severely impacted. However, in the long run, company land would be the fastest segment to recover. Since the Coronavirus emergency could be the cause of one of the better economic lulls in recent memory, it is creating an opportunity for Non-Resident Indians (NRIs). With the pandemic wreaking havoc in the United States and Europe, venture capital openings have plummeted. This has increased the stakes for Indian stocks, as extaps are expected to gradually focus on real estate interests at home. 


\section{CONCLUSION}

The market value of real estate increased during the Covid-19 era. Due to the constrained job market, developers were unable to satisfy demand. This epidemic is oppressive since it is expected to claim thousands of lives. Home values dropped in value as the housing supply decreased, reducing state revenues. Owing to the decline in demand and the increase in negotiating power in the short-supply market, location scouting has already begun, but at a slower pace.

The sector must brace itself for a far direr consequence than was previously expected. With the threat of illness affecting human lives, the real estate division is now observing a decline in property visits and buyer interest. However, the planet has seen comparable outbreaks in the past, for example, SARS virus, bird flu, and so forth, and has successfully recovered. Each cataclysm provides an opportunity to reach new heights. R. E. projects must find motivation in their surroundings to gain an edge by increased growth and indigenous production. The authorities will be wise to halt further virus spread and to take control of the company during times of crisis. Pause and Watch is undoubtedly not the best course of action in the real estate market. As customer desires and opinions are critical for an industry to thrive, businesses can undoubtedly tackle with certain astute responses to pique shopper interest.

\section{REFERENCES}

Adams-Prassl, A., Boneva, T., Golin, M., \& Rauh, C. (2020). Inequality in the Impact of the Coronavirus Shock: Evidence from Real Time Surveys. Journal of Public Economics, 189, 104245. https://doi.org/10.1016/j.jpubeco.2020.104245

Anarock. (2020). Covid-19: Impact on Indian Real Estate. https://www.anarock.com/researchinsights/covid19-impact-on-the-indian-real-estate-sector

Chauhan, A. S., \& Kapoor, S. (2021). Impact of Coronavirus on Indian Real Estate. India Corporate Law. A Cyril Amarchand Mangaldas Blog. https://corporate.cyrilamarchandblogs.com

Cushman \& Wakefield. (2021). India Office Market Report. https://www.cushmanwakefield.com/en/india/insights

Del Giudice, V., De Paola, P., \& Del Giudice, F. P. (2020). COVID-19 Infects Real Estate Markets: Short and Mid-Run Effects on Housing Prices in Campania region (Italy). Social Sciences, 9(7), 114. https://doi.org/10.3390/socsci9070114

D'Lima, W., Lopez, L.A., \& Pradhan, A. (2020). Covid-19 and Housing Market Effects. SSRN Electronic Journal, No. 3647252.

FICCI. (2020). Impact of COVID-19 on Indian Economy. https:/ficci.in/spdocument/23195/Impactof-COVID-19-on-Indian-Economy-FICCI-2003.pdf

Gaidukovs, S., Lyashenko, I., Rombovska, J., \& Gaidukova, G. (2016). Application of Amber Filler for Production of Novel Polyamide Composite Fiber. Textile Research Journal, 86(20), 2127-2139. https://doi.org/10.1177/0040517515621130

Gujral, V., Palter, R., Sanghvi, A., \& Vickery, B. (2020). Commercial Real Estate Must Do More Than Merely Adapt to Coronavirus. McKinsey \& Company. Private Equity \& Principal Investors Practice. https://www.mckinsey.com/industries/private-equity-and-principalinvestors/our-insights/commercial-real-estate-must-do-more-than-merely-adapt-tocoronavirus\#

JLL. (2020). COVID-19 Global Real Estate Implications. https://www.jll.co.uk/en/trends-andinsights/research/covid-19-global-real-estate-implications 
Lašenko, I. L,., Gaidukovs, S., \& Rombovska, J. (2016). Manufacturing of Amber Particles Suitable for Composite Fiber Melt Spinning. The Journal of Latvian Academy of Sciences, 70(2), 51-57. https://doi.org/10.1515/prolas-2016-0007

Milcheva, S. (2020). Volatility and the Cross-Section of Real Estate Equity Returns During Covid19. SSRN Electronic Journal, No. 3599211. https://doi.org/10.2139/ssrn.3599211

Singh, M. K., \& Neog, Y. (2020). Contagion Effect Of COVID-19 Outbreak: Another Recipe for Disaster on Indian Economy. J. Public Affairs, 20(4), e2171. https://doi.org/10.1002/pa.2171

Tanrivermis, H. (2020). Possible Impacts of COVID-19 Outbreak on Real Estate Sector and Possible Changes to Adopt. Journal of Urban Management, 9(3) 263-269. https://doi.org/10.1016/j.jum.2020.08.005

Tupenaite, L., Lill, I., Geipele, I., \& Naimaviciene, J. (2017). Ranking of Sustainability Indicators for Assessment of the New Housing Development Projects: Case of the Baltic States. Resources, 6(4), 55. https://doi.org/10.3390/resources6040055

Uchehara, I., Hamma-Adama, M., Obiri, K. A., Jafarifar, N., \& Moore, D. (2020). Impacts and Risk Management of COVID-19 Pandemic on Real Estate Supply Chain. International Journal of Real Estate Studies, 14(Special Issue 1).

\section{AUTHOR'S SHORT BIOGRAPHY}

Rashmi Sanchaniya has a Master degree in Business Administration from the Gujarat Technological University, Gujarat, India. She has recently participated in the $22^{\text {nd }}$ Annual International Scientific Conference "Economic Science for Rural Development" on 13 May 2021, Jelgava, Latvia. She presented the report "The Role of Entrepreneurship Activity in Economy Development". Her research is related to business and economy.

E-mail: Rashmi.Sanchaniya02@gmail.com 